\title{
Plio-Quaternary prograding clinoform wedges of the western Gulf of Lion continental margin (NW Mediterranean) after the Messinian Salinity Crisis
}

\author{
Johanna Lofi ${ }^{*}$, a b ${ }^{\text {, Marina Rabineau }}{ }^{c}$, Christian Gorini $^{\mathrm{d}}$, Serge Berne ${ }^{\mathrm{a}}$, Georges Clauzon ${ }^{\mathrm{e}}$, \\ Philippe De Clarens ${ }^{f}$, A. Tadeu Dos Reis ${ }^{g}$, Gregory S. Mountain ${ }^{h}$, William B. F. Ryan ${ }^{\text {, }}$, Michael S. \\ Steckler $^{\mathrm{h}}$ and Christine Fouchet ${ }^{\mathrm{a}}$
}

a IFREMER, DRO/GM Technopôle Brest-Iroise, P.O.Box 70, 29280, Plouzané, France

b ISMAR-CNR, Via Gobetti, 101, 40129, Bologna, Italy

c UMR 6538 Domaines océaniques, 1 place Nicolas Copernic, 29280, Plouzane, France

d Université de Lille, SN5 F, 59655, Villeneuve d'Ascq Cédex, France

e CEREGE, Europôle de l'Arbois, 13545, Aix-en-Provence Cédex 04, France

${ }^{f}$ TOTAL FINA ELF, 2, Place de la Coupole, La Défense 6, 92078, Paris la Défense Cédex, France

${ }^{g}$ Department of Oceanography-UERJ, Rua São Francisco Xavier, 524, Rio de Janeiro/RJ, CEP 20550-090, Brazil

h Lamont-Doherty Earth Observatory, Palisades, NY 10964, USA

*: Corresponding author : Tel.: +39 51-639-8868; Fax: +39 51-639-8940

\begin{abstract}
In contrast to the much-studied onshore and deep offshore post-Messinian sedimentary history of the Gulf of Lion, the continental shelf had been poorly explored until recently. New seismic data, acquired by ELF Oil Company on the Languedoc-Roussillon shelf (Western Mediterranean Sea), from Cap Creus in the SW to Cap d'Agde in the NE, together with data from previously drilled exploratory wells, allow us to propose a scenario for margin reconstruction following the Messinian Salinity Crisis. The seismic data display a complex pattern of prograding clinoforms and buried submarine canyons. Following the crisis that eroded the previous margin, clinoforms developed as the new Pliocene margin prograded. Three major periods characterize the evolution of the post-Messinian margin. During the first period, after the filling of the Early Pliocene rias which are now above sea level, the prograding sedimentary prisms rapidly migrated seaward and filled the underlying Messinian topographic lows. The second period consists of a transitional interval, which began with a pronounced fall in sea level that probably corresponded with the end of the Lower Pliocene. Deposits were disturbed by large slumped structures. The third period is characterized by the appearance and development of submarine canyons near the subsequent shelf edges, maybe as a result of the increased glaciations and related sea-level changes. From that time onward, most of the Late Pliocene and Quaternary sediments were directly transferred down to the deep basin.
\end{abstract}

Keywords: Mediterranean Sea; Gulf of Lion margin, clinoform; progradation; submarine canyon; Messinian Salinity Crisis; Plio-Quaternary 


\section{Introduction}

Since the discovery of diapirs and salt layers in the Mediterranean Sea (Menard et al., 1965; Auzende et al., 1971; Ryan, 1973), a huge amount of work has been devoted to the study of the Messinian Salinity Crisis (Hsü et al., 1973) and the Plio-Quaternary sedimentation on the Mediterranean margins. However, in the Gulf of Lion (Fig. 1), as elsewhere, most of these studies focused either on detailed analysis of outcrops on the onshore portion of the continental margin (Clauzon, 1982; Calvet, 1986) or on seismic interpretation of deep-water Plio-Quaternary deposits (Droz, 1991; Torres, 1995; Berné et al., 1999). Until recently, the architecture of Plio-Quaternary continental shelf sedimentary sequences, a key element for understanding the reconstruction of the continental margin, was known only from a few profiles and borehole reconstructions (Biju-Duval et al., 1974; Mauffret and Gorini, 1996). Only the late Quaternary deposits had been subject to detailed investigations (Aloisi, 1986; Tesson et al., 1990; Berné et al. 1998; Rabineau, 2001).

Thanks to a new set of multi-channel seismic data acquired by ELF Oil Company in 1996, it is now possible to present a preliminary interpretation of Plio-Quaternary evolution of the Languedoc-Roussillon platform tied to the bio-stratigraphic interpretation of some exploratory wells (Cravatte et al., 1974). We have carried out seismic mapping and interpretation with the objective of documenting the three-dimensional geometry of PlioQuaternary shelf deposits on the margin. The new seismic data show prograding Pliocene clinoforms incised by numerous large submarine canyons on the outer shelf. 


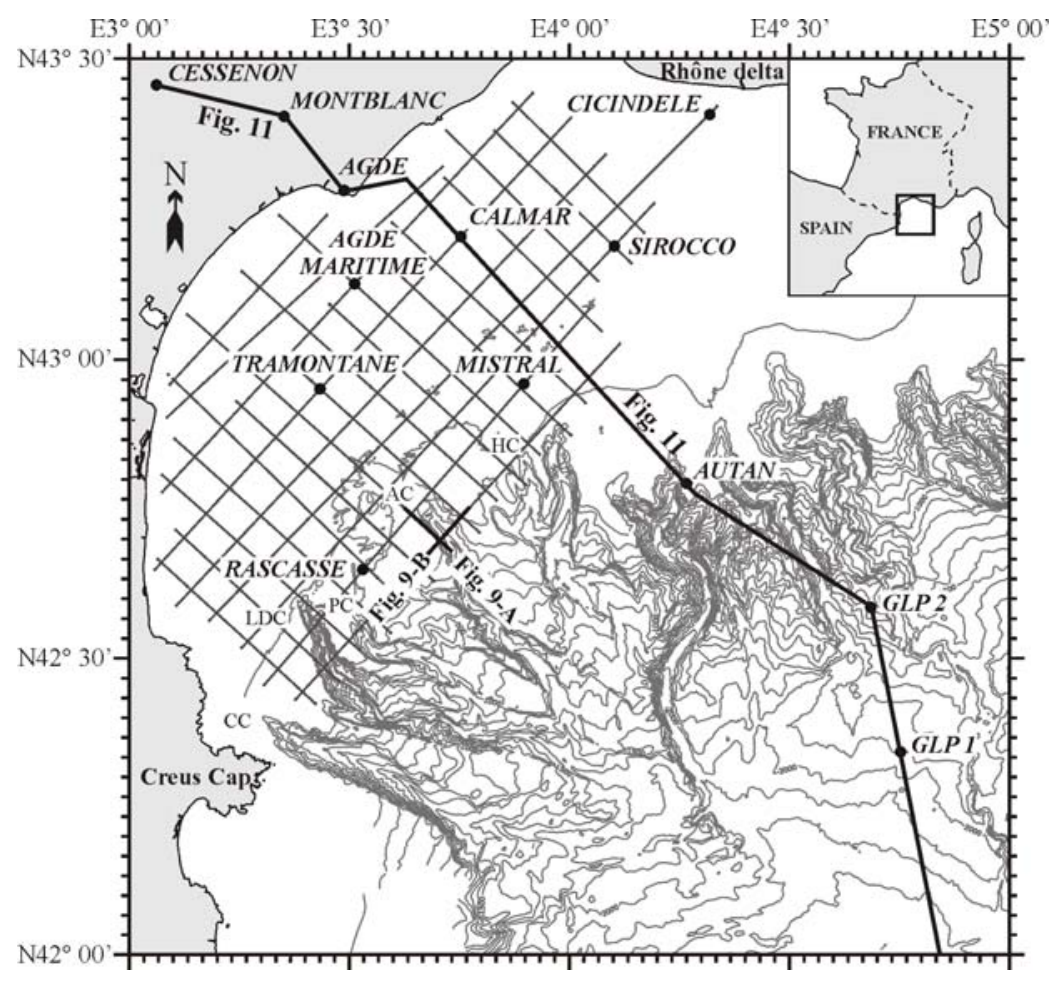

Figure 1. Simplified bathymetric map of the Gulf of Lion shelf showing location of the study area, the grid of seismic lines and the exploratory wells. The heavy lines refer to the composite line illustrated in figure 11 . Water depths are in meters. CC: Creus Canyon; LDC: Lacaze-Duthiers Canyon; PC: Pruvost Canyon; AC : Aude (or Bourcart) Canyon; HC : Herault Canyon.

\section{General setting}

The present study was carried out on the western part of the Gulf of Lion continental shelf, which forms the western termination of the Provençal Basin. The platform is about 250 $\mathrm{km}$ long and $75 \mathrm{~km}$ wide, bounded to the northeast by the Alpine orogenic belt and to the southwest by the Pyrenees. This shelf is relatively flat and slopes gently seaward to the shelf break that is located at a depth between 120 and $150 \mathrm{~m}$ and incised by numerous submarine canyons (Fig. 1).

\subsection{Geological setting}

The Gulf of Lion margin is a result of Oligo-Aquitanian rifting and Burdigalian crustal separation between continental Europe and the Corsica-Sardinia microplate (Alvarez, 1972; 
Biju-Duval et al., 1974). The rifting occurred between 30 and $21 \mathrm{Ma}$, and a distinct synrift sequence is visible on seismic sections. It is composed of sandy shales. The post-rift sedimentation is characterized by clastic sedimentation including Early Miocene turbiditic shales. Then, in the late Miocene, an evaporitic sequence was deposited in the deep basin during the Messinian followed by a thick Pliocene-Quaternary mega-sequence. The thickness of the post-rift sequence increases toward the center of the basin, where it reaches more than 7 $\mathrm{km}$.

The evolution of this margin is comparable to that of the Atlantic margins, although its age is only 30 Ma (Steckler and Watts, 1980). The initial subsidence pattern of the Gulf of Lion was generally rapid, followed by a slower rate of post-rift subsidence (Bessis and Burrus, 1986), without any significant tectonic activity. It has been suggested that the subsidence rate accelerated in the deeper part of the margin during the last 5 million years (Burrus et Audebert, 1990). The basic mechanism for post-rift subsidence is thermal relaxation, but the loading effect of the sediment contributes 40 to $50 \%$ to the total subsidence of the margin (Bessis and Burrus, 1986).

\subsection{The Messinian Salinity Crisis (Hsü et al., 1973)}

The post rifting sedimentation in the Gulf of Lion area was strongly influenced by the Messinian Salinity Crisis (Hsü et al., 1973), which started 5.96 Ma ago (Gautier et al., 1994; Krijgsman et al., 1999). As a combined consequence of a global fall in sea level, coupled with uplift of the Gibraltar Strait region during the Lower to Upper Messinian, the two-way connection between the Atlantic Ocean and the Mediterranean Basin was gradually shut down, provoking a dramatic fall in sea-level of about $1900 \mathrm{~m}$ in the Mediterranean basin (Ryan, 1976; Clauzon, 1982). This fall in sea level was favored by the pre-existing xerothermic climatic conditions around the Mediterranean area (Suc and Bessais, 1990). As a direct consequence of this sea level drawdown, two major seismic markers are identified in 
the Mediterranean basin. (1) The increase in water salinity during the crisis resulted in the deposition of up to 1400 m-thick evaporites in the deep basin. Also there was a controversy regarding the conditions in which these evaporites formed (Nesteroff, 1973), the "desiccated deep-basin model" proposed by Hsü et al. (1973) is now widely accepted. (2) The simultaneous exposure of the margins generated a widespread erosional surface called the "Messinian erosional surface" (Cita and Ryan, 1978). This discontinuity is characterized by the occurrence of deep incisions in the hinterlands, caused by paleorivers in response to the huge base-level fall (Clauzon, 1982; Barber, 1981). Guennoc et al. (2000) published the detailed morphology of this erosion on the Gulf of Lion platform. Their map shows the existence of two main Messinian valleys (sub-aerial canyons): the Rhône valley system to the northeast, and the Languedoc-Roussillon valley system to the southwest. They are separated from each other by a topographic high: the Sétoise high. Two Messinian detrital deposits resulting from margin erosion are found seaward of the Languedoc-Roussillon system (Lofi, 2002). Our paper focuses on the Post-Messinian continental margin reconstruction in the area of the Languedoc-Roussillon valley system.

\subsection{Post Messinian climate and sea-level changes history.}

The rise in global sea-level at the beginning of the Lower Pliocene (Haq et al., 1987), probably combined with a change in the tectonic activity in the Alboran Sea, caused the flooding of the desiccated basin at 5.32 Ma (Zanclean transgression). This rise in sea level marked the end of the salinity crisis with the re-establishment of open marine conditions in the Mediterranean, and the beginning of Pliocene sedimentation on the Gulf of Lion platform. From that time onward, the Lower Pliocene is marked by a long period (about 1.5 Ma) of high sea level characterized by the sedimentary filling of the Early Pliocene rias (Clauzon et al., 1987).

The $\delta^{18} \mathrm{O}$ records of the last $5 \mathrm{Ma}$ available from deep sea successions in the Mediterranean 
Sea document a clear climatic deterioration which occurred in discrete steps, making the transition between the warm climates of the Messinian to the cooler climate of the Pleistocene (Shackleton et al., 1995). The isotopic signal and its global climatic significance are supported by palynological data attesting to the existence of major cooling events since the beginning of the Pliocene (Suc et al., 1995). The Lower Pliocene displays short term, low amplitude fluctuations in temperature, and was warmer and dryer than any earlier period (Suc et al., 1995). A first major cooling event is recorded around 3.5 Ma and corresponds with a significant change in the global climate due to the extension of continental ice sheets to the Northern Hemisphere (Keigwin and Thunnel, 1979; Zachos et al., 2001). This cooling event is marked by a fall in global sea level corresponding to the TB 3.4-3.5 cycle fall of Haq et al. (1987). A second cooling event around 2.6 Ma is recorded near the end of the Middle Pliocene. It follows the emergence of the earliest glacial-interglacial cycles in the northern hemisphere since 3-3.2 Ma (Shackleton et al., 1995, Zachos et al., 2001), with an increase in ice rafting in the open North Atlantic (Backman, 1979). From that time onward, an increase in rapid climatic variations is observed, as polar ice caps changed in volume, and high frequency fluctuations in relative sea level are recorded.

\section{Methods}

\subsection{Seismic data}

The geophysical data (LRM96 seismic lines) were acquired by ELF Oil Company in 1996, in the western part of the Gulf of Lion area, from the Cap Creus in the SW to the Cap d'Agde in the NE (Fig. 1). The seismic grid, covering a total area of more than $4000 \mathrm{~km}^{2}$, consists of 16 dip-sections and 9 strike-sections, with a spacing ranging from 5,5 to $18 \mathrm{~km}$. The high quality of the LRM96 seismic lines, compared to previous oil-industry seismic data (Gorini, 1993), is attributed to the use of a tuned air-gun. The profiles display a resolution of 
about 25 to 30 meters. We did not have access to the numerical data and did not re-process the lines. Nevertheless, the profiles were scanned and the resulting images were processed using a median filter in order to increase the readability of the seismic lines presented in this paper.

Analysis of the seismic data following a classical seismic stratigraphic procedure (in terms of reflection endings -erosional truncation, onlap, downlap- and configurations) allowed the identification of seismic units and their boundaries (Mitchum and Vail, 1977).

\subsection{Exploratory wells and stratigraphic correlation}

Data from nine exploratory boreholes are available over the study area. They are located on the inner and middle shelf, except Autan 1, drilled on the shelf edge, and GLP1 and GLP2, drilled at the continental slope (see Fig. 1 for location). The seismic units have been connected to the boreholes using velocity law described in section 3.3. The drilling reports for each well allowed an interpretation of the units essentially in terms of depositional environments. The first 3-4 hundred meters of sediments (essentially Middle Pliocene to Quaternary deposits) were rarely recovered. Therefore, the chronostratigraphic resolution is rather limited, and the position of the Plio-Quaternary stratigraphic boundaries remains uncertain.

Detailed analyses of planktonic foraminifera have been carried out on four of the wells by Cravatte et al. (1974). Their work was reviewed on the basis of the new biostratigraphic scheme proposed by Cita et al. (1999) that includes 6 biozones for the Pliocene (from MPL 1 to MPL 6) and 2 biozones for the Pleistocene strata (Fig. 2). In this study, we adopted the threefold chronostratigraphic subdivision of the Pliocene series proposed by Cita et al. (1999) and based on well-established stratotype boundaries. The Miocene-Pliocene boundary corresponds to the reestablishment of open marine conditions in the Mediterranean after the 
Messinian Salinity Crisis and supports the widely accepted concept of the Pliocene transgression.

\subsection{Time-depth conversions}

We compiled stacking velocities from the seismic data to compute depth sections from the travel time, for the Plio-Quaternary cover. This was done by using stacking velocities posted at various cdp's along LRM96 lines (Lofi, 2002). We imposed a uniform 1500 m/sec for the velocity of sound in water. The velocity law obtained for the conversions is as follows:

$$
D m=-0.0002 x T^{3}+0,6238 x T^{2}+788,95 x T
$$

$D m$ is the calculated depth (m) and $T$ the travel time below sea floor measured on the seismic profiles (millisecond two-way traveltime (msec TWTT)). This velocity law has been validated using borehole data. We restored the present day depth of the Messinian discordance from seismic data, using velocity law. The difference between depth provided by boreholes and depth calculated from the seismic lines does not exceed 5\%. 


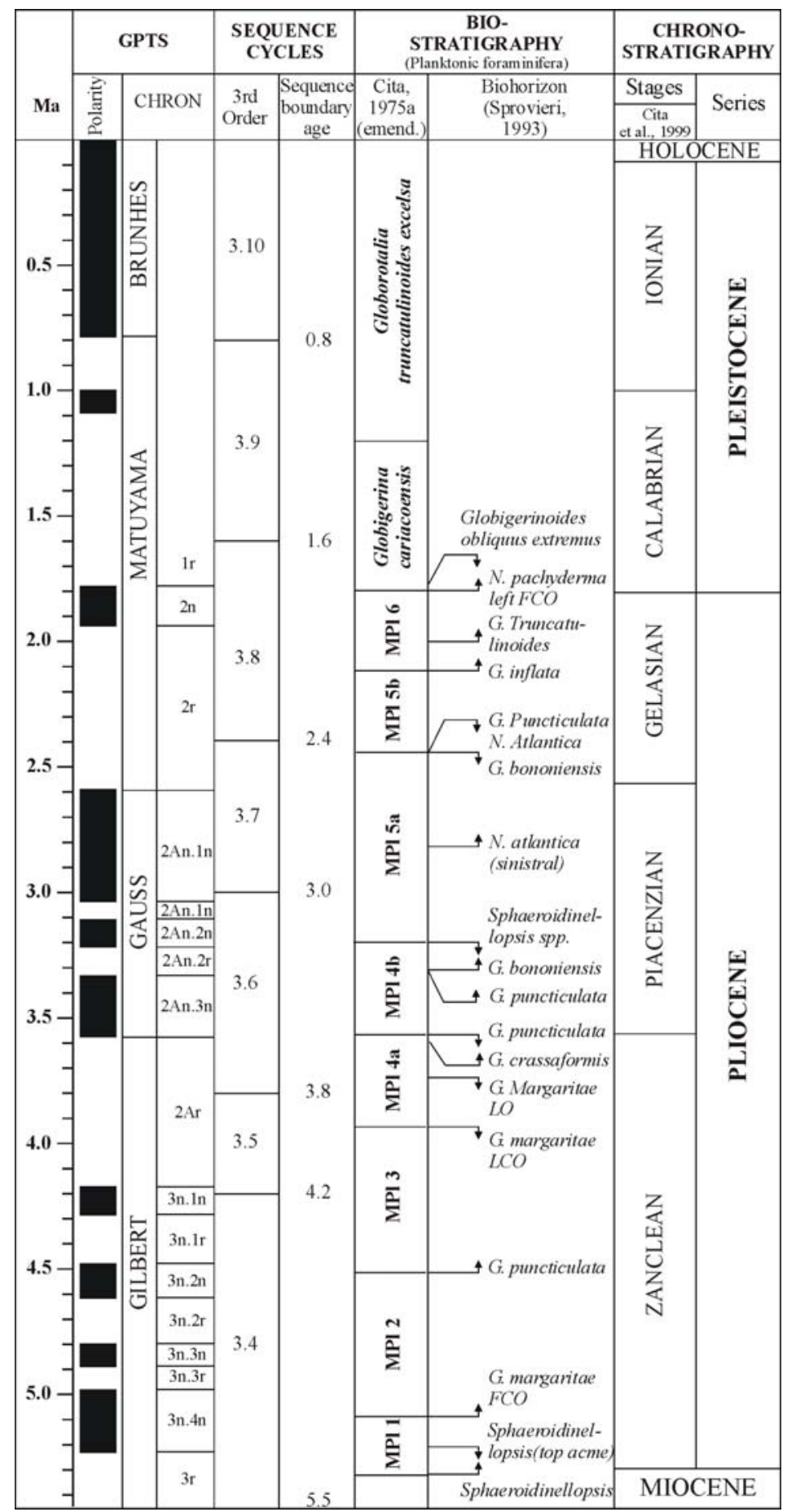

Figure 2. Integrated Mediterranean Pliocene-Pleistocene time framework (modified from Cita, 1999 and Lourens et al., 1996). Geomagnetic Polarity Time scale is after Hilgen (1991). Abbreviations are FCO, first common occurrence; FO, first occurrence; LCO, last common occurrence; and LO, last occurrence. 


\section{Results}

\subsection{Seismic stratigraphy}

The architecture of Plio-Quaternary deposits in the western Gulf of Lion continental margin is illustrated in figure 3. This interval consists of thick prograding clinoform wedges (up to $2000 \mathrm{~m}$ beneath the present outer shelf) indicating an overall seaward progradation of the margin since the end of the Messinian Salinity Crisis.
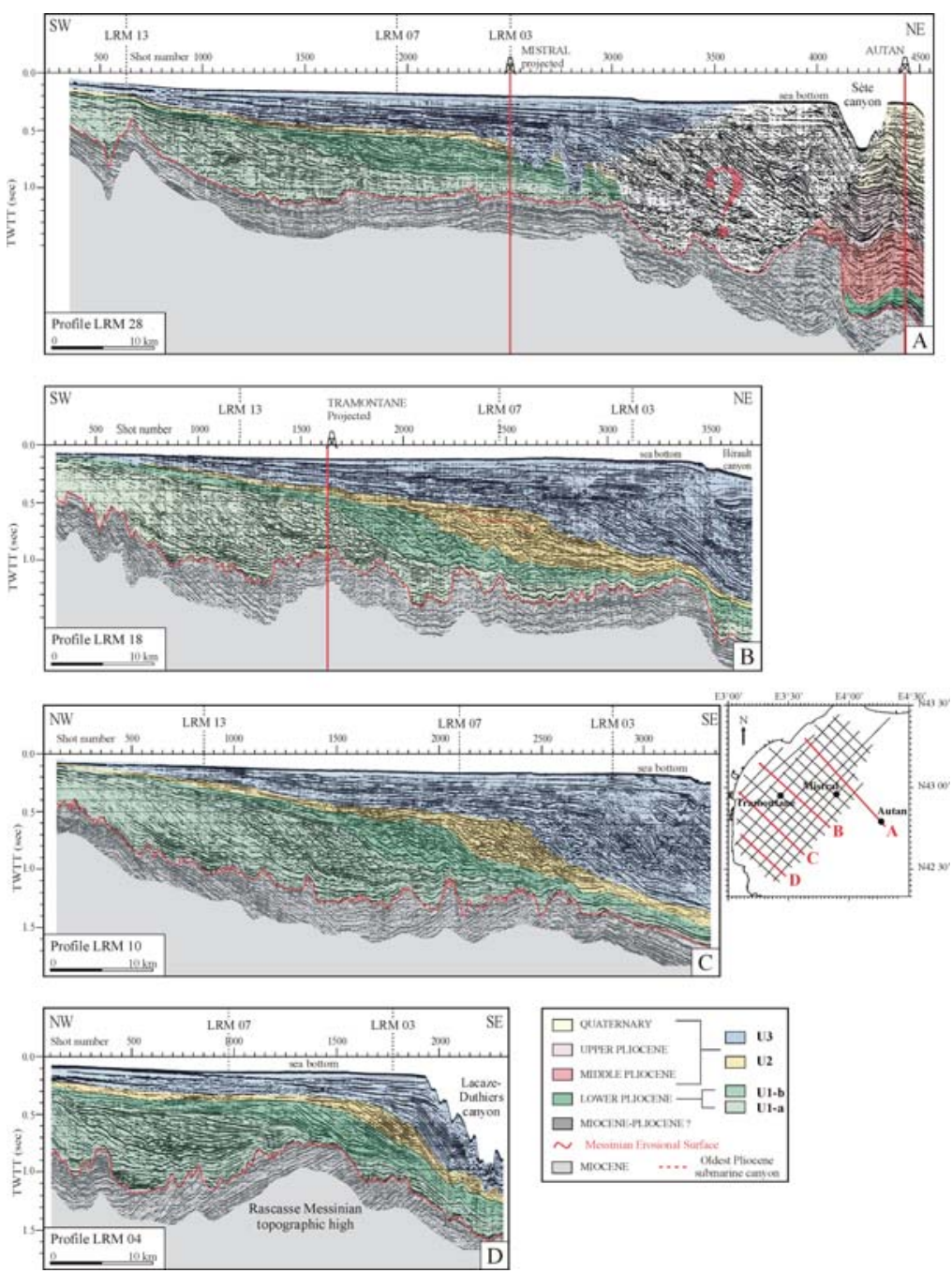

Fig. 3 - Interpreted dip seismic profiles LRM28 (A), LRM18 (B), LRM10 (C) and LRM04 (D) showing the global organisation of the Plio-Quaternary deposits on the shelf. The Messinian discordance (MD) is overlaid by prograding clinoforms filling the Messinian topographic lows. Distinct deeply incised paleo-submarine canyons are observed in the vicinity of the shelf break. 


\subsubsection{Seismic facies}

Six key seismic facies, listed below, were identified on our seismic data set (Fig. 4):

Parallel to divergent facies (Fig. 4-A) is represented by variably continuous high-amplitude reflections and predominates over the inner to middle shelf within the upper sequences. This facies is interpreted as a shallow marine sedimentary environment (situated landward of the offlap break). Reflections are locally disrupted on the inner shelf by erosional structures filled either by parallel, transparent or chaotic reflections (Fig. 4-A). On the outer shelf, canyon head incisions that are connected to the continental slope deeply cut seismic reflections and commonly interrupt their lateral continuity.

Oblique to sigmoïd clinoform facies are usually represented by moderate- to high- amplitude complex seismic reflections, showing a distinct topset/foreset/bottomset relationship (Fig. 3). This facies is characteristic of prograding units and corresponds to slope deposits. Beneath the middle to outer shelf, it is often disturbed by mass failures or erosional structures.

Draping parallel facies (Fig. 4-B) is represented by continuous low- to high-amplitude gently dipping drape reflections. It is developed at the base of the clinoforms and drape across the Messinian erosional surface. This seismic facies is interpreted as low energy, deep-water deposits.

Transparent facies is represented by discontinuous low-amplitude reflections (Fig. 4-C). It is observed beneath the inner shelf (Fig. 5). The few visible reflections are sub-parallel to divergent or locally oblique to sigmoid (Fig. 3-C, shot points 100 to 900) and are interpreted as shallow marine-to-slope depositional environments. In figure 3-B, transparent clinoforms pass progressively to non-transparent, high-amplitude clinoforms (Fig. 3-C, shot points 900 to 1300). This lateral (and temporal) variation may result from a change in the type of sediment supplied by rivers as the shelf prograded over the Messinian surface.

Hummocky facies (Fig 4-D) represented by "hummocky" or wavy reflections, is mainly present in the central zone of the study area. This facies is limited to the Languedoc- 
Roussillon Messinian valley axis, filling Messinian bathymetric lows (Fig. 5). We interpret this facies as the product of instabilities along the paleo-slope.

Chaotic facies is represented by discontinuous, disorganized reflections. It is locally reflection-free (Fig. 4-E). Its lateral extension is limited to the eastward area of the Messinian Sétoise topographic high, and is probably linked to the Rhone river system (Fig. 5). This seismic facies may result from incised-valley fills, biogenic gas, as well as coarse-grained sediments supplied by the rivers. Chaotic facies are also observed at random points within slides and slumped areas or infills of paleocanyons and paleovalleys.

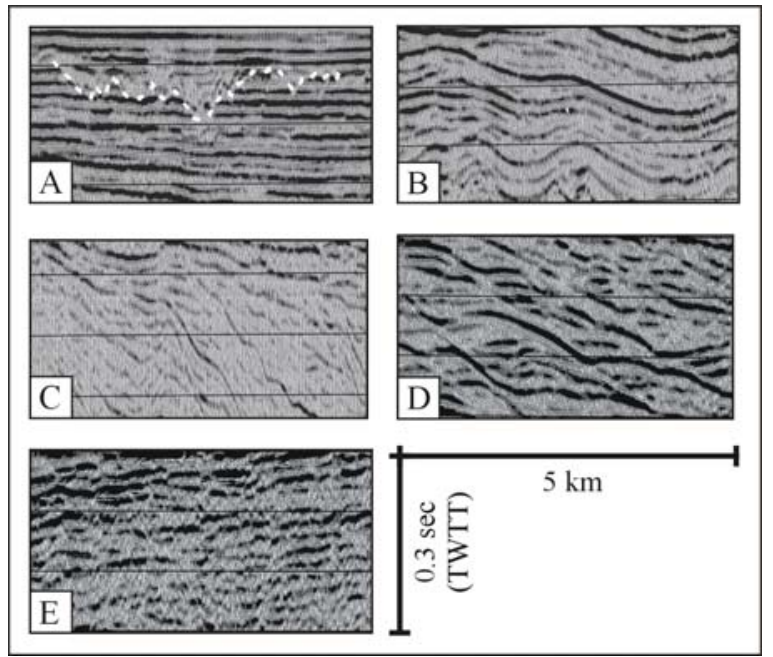

Figure 4. Seismic facies identified in the study area: (A) Parallel to divergent facies. Reflections are locally disrupted by (fluvial ?) erosion structures. (B) Draping parallel facies; (C) Transparent sigmoïde clinoform facies; (D) Hummocky facies and (E) Chaotic facies. The clinoform facies is shown in figure 3. 


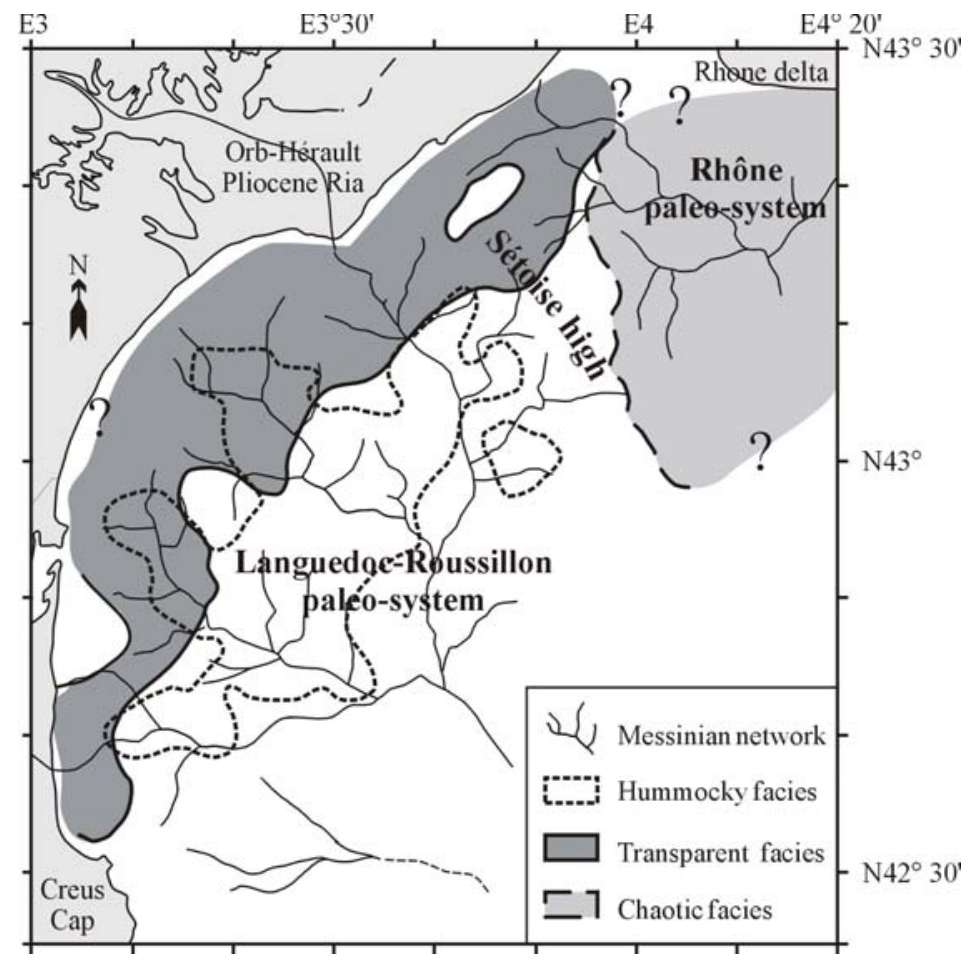

Figure 5. Simplified map of major Messinian valleys of the Gulf of Lion platform showing the relationship between the Messinian topography and the extension of the hummocky, transparent and chaotic seismic facies.

\subsubsection{Seismic units and boundaries}

The architecture of the Plio-Quaternary interval displayed by seismic profiles is rather complex, with evidence of numerous discontinuities. Not all of them have the same level of importance, and we attempted to establish a hierarchy of bounding surfaces.

At the base of the deposits, a major discontinuity is easily correlated throughout the study area and corresponds to the Messinian erosional surface (MES). Borehole correlation attests to its late Messinian age (Cravatte et al., 1974) (Fig. 6 and 7). The MES truncates the underlying faulted Miocene seismic reflectors (in gray color in figures 3 and 6 to 8) and an angular difference in reflector geometry between pre- and post-Messinian sequences is commonly observed (ex. Fig. 3-D, shot points 1000 to 2000). The MES displays high relief beneath the present inner and middle shelf, which attests to the spectacular erosion of the margin during the crisis (Fig. 8-A). 
Above the MES, interpretation of the Plio-Quaternary deposits allows for their subdivision into a number of distinct seismic units. These units are comprised of topsets, clinoforms and bottomsets, and are typical of prograding basin-margin systems (Steckler et al., 1999). Most of their bounding surfaces are erosional truncation (upper boundary of the units) and downlap or onlap surfaces (lower boundary of the units). In deep-water environments, the discontinuities become correlative conformities. Because of the seismic complexity of the Plio-Quaternary sequences, and the large spacing of the seismic grid, only the major seismic units were correlated throughout the margin. We successively mapped 3 main units labeled U1, U2 and U3 from the oldest to the recent most. They are respectively colored in green, yellow and blue in Figures 3, 6 and 7. We labeled U1(s) and U2(s) the boundaries above seismic units U1 and U2, respectively.
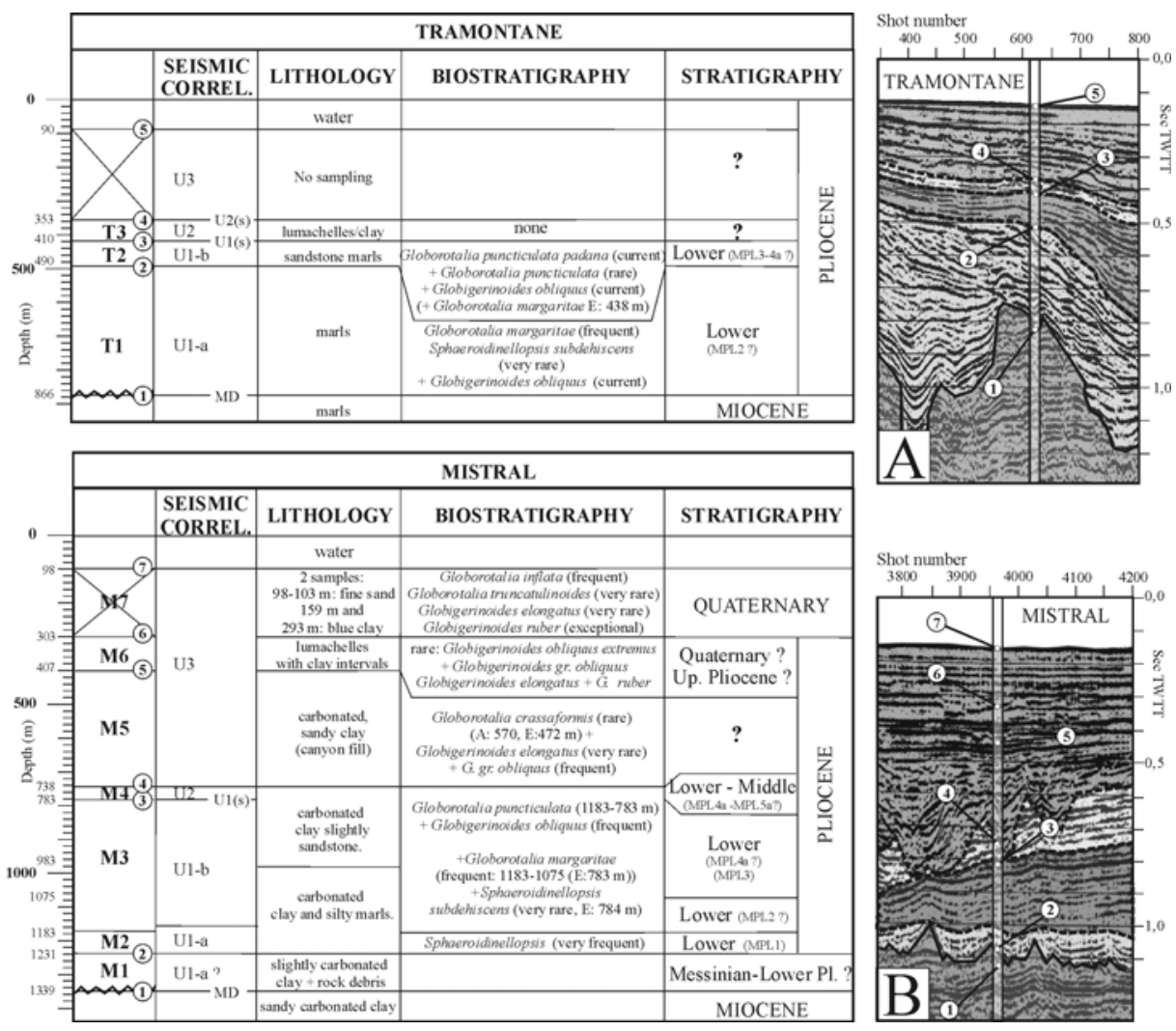

Figure 6. Stratigraphic correlations between seismic lines and the Tramontane (A) and Mistral (B) exploratory wells drilled in the area (see position in Fig. 1). Borehole description is after the work of Cravatte et al. (1974). The Messinian unconformity is clearly identified and easily correlated with the seismic data; the Middle Pliocene to Quaternary lower limits remain uncertain. Abbreviations are A: appearance; E: extinction. Circled numbers on seismic profiles correspond to the boundaries of intervals identified on borehole data, using our velocity law. 


\subsection{Borehole description}

Because of the extremely low stratigraphic resolution of the data of some of the wells of the Gulf of Lion, the lithologic and biostratigraphic analysis of the data from only two boreholes is discussed hereafter (see also Fig. 6-A and 6-B). Descriptions are after the work of Cravatte et al. (1974). In addition, we used a third borehole, located at the shelf edge, for chronostratigraphic correlation (Fig. 7).
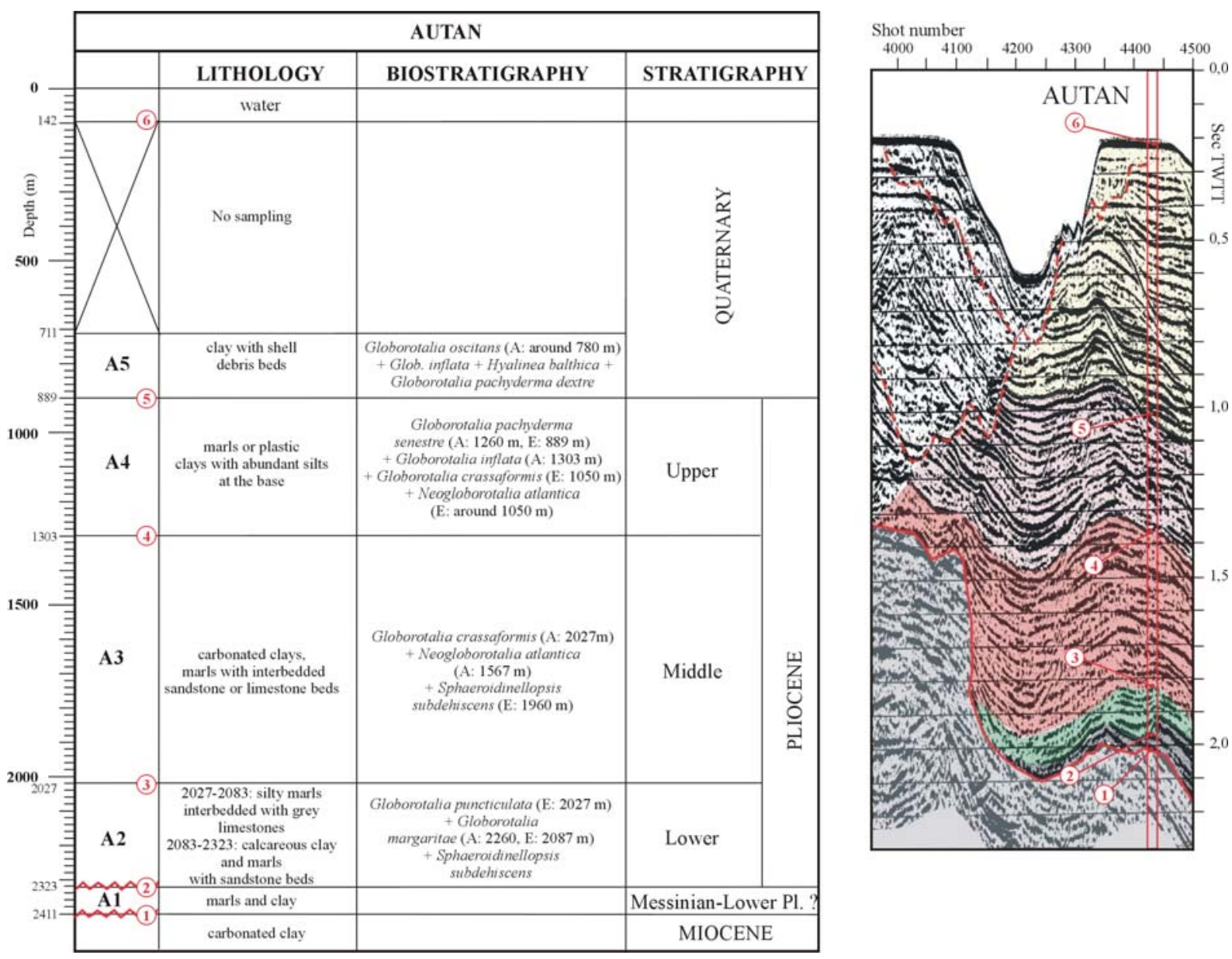

Figure 7. Stratigraphic correlations between seismic line LRM28 and the Autan exploratory wells (see Fig. 1 for location). Borehole description is after the work of Cravatte et al. (1974) and Cravatte and Suc (1981). A: appearance, E: extinction. Circled numbers on seismic profiles correspond to the boundaries of intervals identified on borehole data, using our velocity law. 


\subsubsection{Tramontane}

Facies successions at "Tramontane” suggest a decrease in water depth from an upper slope to middle shelf depositional environment. Lithologic and biostratigraphic analysis permitted us to distinguish three distinct intervals (T1, T2 and T3) within the Plio-Quaternary (Fig. 6-A):

Interval T1 deposited above the MES consists of silty marls with rare Echinoderm and Lamellibranch debris. Biostratigraphy confines these deposits to the end of the Lower Pliocene with the occurrence of Globorotalia margaritae (first common occurrence (FCO) at 5.10 Ma and last common occurrence (LCO) at $3.94 \mathrm{Ma}$ ). Because of the absence of Globorotalia puncticulata (FO at $4.52 \mathrm{Ma}$ ) and the rarity of Sphaeroidinellopsis subdehiscens, this interval may correspond to biozone MPL 2 (Fig. 2).

Interval T2 consists of sandy marls with shell debris at the top. It has been reported by Cravatte et al. (1974) to belong to the Middle Pliocene with the occurrence of Globorotalia puncticulata padana. Nevertheless, the authors observed some anomalies such as the presence of Globorotalia margaritae (a badly preserved specimen which might have been redeposited), or the occurrence of Globorotalia puncticulata padana in association with Globorotalia puncticulata. Consequently, we believe that this interval may also have been deposited during the Lower Pliocene (biozone MPL 3, Fig. 2). This hypothesis is confirmed by the seismic correlation of T2 with the Mistral borehole: T2 is partly contemporaneous to M3 interval of “Mistral”, which is Early Pliocene (see Mistral description and Fig. 6).

$\underline{\text { Interval T3 }}$ consists of carbonated clay interbedded with lumachelles containing Echinoderm debris. No sample allows for precise biostratigraphy of this interval. Cravatte et al. (1974) attributed T3 to the Upper Pliocene by analogy with the late Pliocene lumachelles drilled at the Mistral borehole (see interval M6 from Mistral). However, our seismic correlation shows that interval T3 from Tramontane and interval M6 from Mistral are not contemporaneous. 
Interval T3, older than M6, is Pliocene in age and cannot be dated more precisely. Sediments above T3 were not sampled during the drilling operations.

\subsubsection{Mistral}

Lithology and biostratigraphy from the Mistral borehole permit us to distinguish seven distinct intervals within the deposits overlying the MES, recovered at a depth of $1339 \mathrm{~m}$ (Fig. 6-B):

Interval M1 consists of sandy clay with abundant millimetric to multi-centimetric rocky debris. It contains few benthic specimens characterizing a littoral sedimentary environment. Cravatte et al. (1974) reported the presence of few specimens of Globorotalia margaritae, G. puncticulata and Sphaeroidinellopsis in this interval. According to the authors, their presence is due to technical problems encountered during the sounding, at this depth precisely. No other biostratigraphic specimen permits us to date precisely this interval, which has been attributed, either to the Basal Pliocene or to the Tortonian. On our seismic data, this heterogeneous level is situated immediately above the MES (Fig. 6-B). We consequently believe that these littoral deposits may have been deposited when the shoreline was close to the Mistral borehole during the Messinian Salinity Crisis sea level fall or during the sea level rise marking its end at the beginning of the Pliocene.

Interval M2 consists of an homogeneous interval of carbonated clay. Because of the frequent appearance Sphaeroidinellopsis subdehiscens (acme) and the absence of Globorotalia margaritae (though, in fact, a very few specimen of G. margaritae can be found in these sediments), we attributed this interval to the biozone MPL 1 characterizing the base of the Zanclean (Fig. 2).

Interval M3 consists of carbonated clay with clastic debris at the top. Biostratigraphy confines these deposits to the end of the Lower Pliocene with the occurrence of Globorotalia margaritae in association with Globorotalia puncticulata. We attributed this interval to the 
biozone MPL 3 (LCO of G. margaritae at 3.98). Nevertheless, it could also partly correspond to the biozone MPL 4a (LO of G. margaritae at 3.81, LO of G. puncticulata at 3,57). The base of the M3 interval (1075-1183 m) is characterized by the frequent appearance of Globorotalia margaritae and could correspond to the biozone MPL2.

Interval M4 is characterized by the occurrence of Globorotalia puncticulata without Globorotalia margaritae. As G. puncticulata disappeared in the Mediterranean at 3.57 Ma but reappeared at 3.31 Ma and disappeared definitely at 2.41 Ma (Lourens et al., 1996), this interval consequently could be either Early Pliocene (top of biozone MPL4a) or Middle Pliocene (biozones MPL4b, MPL5a) in age. Faunal indications show a gradual decrease in the depositional depth from the beginning of M2 to the end of M4, from an outer shelf-upper slope to a middle shelf environment. This reflects the decrease in water depth as the margin progrades.

$\underline{\text { Interval M5 }}$ consists of carbonated sandy clays. We lack biostratigraphic information. Benthic fauna indicates a middle shelf depositional environment and at the beginning of the period, a sandy level is interpreted by Cravatte et al. (1974) as a littoral deposit. Our seismic correlations show that M5 corresponds to a canyon infill. The sandy deposits sampled at the base of the interval correlate with the base of the canyon on the seismic profile and might therefore correspond to canyon infill detrital sediments rather than to littoral deposits. The presence of Globorotalia crassaformis indicates that this infill is younger than 3.60 Ma.

$\underline{\text { Interval M6 }}$ consists of lumachelles containing gastropods and lamellibranchs, interspersed with sandstone or carbonated clays. Benthic microfauna confirms the littoral character of the sedimentary environment (with brackish influences). Specimens of both Globigerinoides obliquus extremus and Globigerinoides gr. obliquus (last occurrence at $1.77 \mathrm{Ma}$ ) were recovered from clays within this interval. Cravatte et al. (1974) consequently assigned an upper Pliocene age to interval M6. The sedimentary environment of that interval is very shallow so the Pliocene Foraminifera may be reworked. Interval M6 could thus be partly or 
totally Quaternary in age. However no Quaternary specimens have been sampled in this interval.

Interval M7: The upper hundred meters of sediment were not recovered so the Quaternary lower limit is still unknown on the Gulf of Lion platform. A sample directly taken from the drilling tools allowed for a punctual analysis of the benthic and planktonic microfauna. The occurrence of Globorotalia inflata (FO at 2.13 Ma (Comas et al, 1996) or at 1.99 (Berggren et al., 1995)) at a depth of 293 meters and of Globorotalia truncatulinoides (FO at $2.00 \mathrm{Ma}$ ) at a depth of $303 \mathrm{~m}$ permitted us to assign interval M7 to the Quaternary (younger than 2.00 Ma). Facies succession at the Mistral borehole suggests a diminution of the depositional environment depth from an upper slope (M2) to a middle shelf environment (M7). Correlations between our seismic data and the Autan borehole (Fig. 7) have not been possible because of the submarine incisions on the outer shelf and slope (Fig. 8-A, shot points 2700 to 4500).

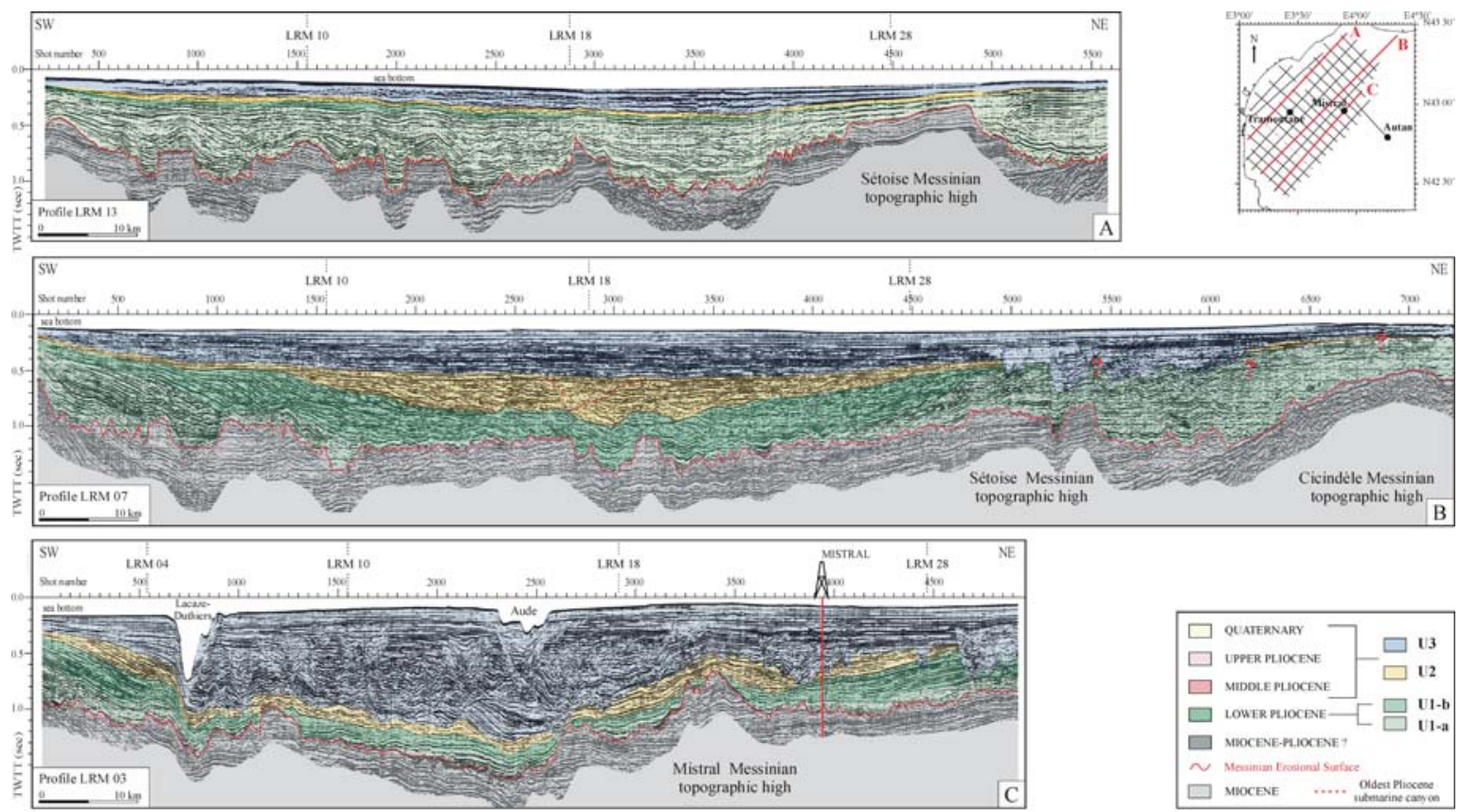

Figure 8. Interpreted strike seismic profiles LRM13 (A), LRM07 (B) and LRM03 (C) showing the global organisation of the Plio-Quaternary deposits on the Languedoc-Roussillon shelf. The Messinian erosional surface (MES) is overlaid by clinoforms filling the Messinian topographic lows. The oldest paleo-canyon is observed in the axial part of the Languedoc-Roussillon Messinian valley. 


\subsection{Correlation of seismic data with borehole information}

Seismic units have been tied to biostratigraphy and facies data from the wells. Correlations show that Lower Pliocene deposits are mainly located beneath the modern innerto middle-shelf (Fig. 3 and Fig. 8), whereas Middle Pliocene to Quaternary sediments are more abundant beneath the middle-to outer shelf (Fig. 3 and Fig. 8). Seismic stratigraphy above unit U1 is highly complex, and multiple truncations by ancient and modern canyons limit the potential for effective interpretation and mapping from existing data (Fig. 3-A, shot points 2700 to 4500 and Fig. 8-C). A fuller understanding of this interval would require additional seismic data of higher resolution and full-recovery boreholes.

\subsubsection{Unit $U 1$}

Unit U1 consists of regular prograding clinoforms deposited beneath the modern inner- to middle-shelf and is colored in green on the seismic lines illustrated in figures 3 and 8. It is Early Pliocene in age (Fig. 6). Lithology and biostratigraphy from the Tramontane borehole permit us to refine the seismic interpretation and to distinguish two sub-units: U1-a and U1-b that correspond to similar intervals on the boreholes.

- The lower sub-unit (U1-a) deposited over the MES is illustrated in light green in the seismic lines. It correlates with the interval T1 from the Tramontane borehole and with the base of the interval M2 from the Mistral borehole. Both intervals are Early Pliocene in age, and U1-a is undoubtedly dated from the Lower Pliocene.

- $\quad$ The upper sub-unit (U1-b) correlates with interval T2 from the Tramontane borehole and the middle and top of interval M2 from Mistral. It is illustrated in dark green on the seismic lines and dated from the Lower Pliocene on the Mistral borehole (Fig. 6-B).

The shallowing-upward facies observed in the boreholes reflect the progradation of the margin and the infilling of the Messinian topographic lows during the deposition of U1 (during the Lower Pliocene). We assign a major importance to U1(s) (U1 upper boundary) 
that we interpret as an erosional unconformity formed during a relative fall in sea level. Because of the age of U1 (Lower Pliocene, MPL1 to MPL3-4a ?), we suggest that this relative fall in sea-level could be associated to the TB 3.4/3.5 cycle regression with a sequence boundary that occurred around 3.8 Ma, close to the end of the Lower Pliocene, suggesting a probable cooling in the climate around the boundary between the Lower and Middle Pliocene.

\subsubsection{Unit $U 2$}

Unit U2 consists of prograding clinoforms deposited beneath the modern middle shelf and was affected by large slumps or slides. It is colored in yellow on the seismic lines. It has been tied to T3 and partially M4 from the Tramontane and Mistral boreholes respectively and no biostratigraphic evidence permits precise dating. At Tramontane, U2 consists of at least 60 meters of lumachelles interpreted as inner- to middle-shelf deposits overlying upper slope to outer shelf marly deposits of U1. Considering the age assigned to U1(s), we believe that unit U2 is Middle Pliocene in age. This is partly supported by the occurrence of G. Puncticulata without G. Margaritae in the M4 interval from the Mistral borehole, which might be attributed to the Middle Pliocene.

The upper limit of U2 cannot be dated precisely as its surface has been incised by a submarine canyon at the Mistral borehole and sediments above U2(s) have not been sampled at Tramontane. We assign a major significance to this surface, because from that time onward, submarine canyon incisions increased considerably in size and number (Fig. 6-A and 8).

\subsubsection{Unit $U 3$}

Unit U3 consists of regular prograding clinoforms deposited beneath the modern outer shelf and is characterized by large submarine canyon incisions. It is colored in blue on the seismic lines illustrated in figures 3 and 8. Unit U3 has been tied to M5, M6 and M7 intervals 
at the Mistral borehole and has not been sampled at the Tramontane one. This unit cannot be dated precisely and is Middle Pliocene to Quaternary in age.

\subsection{Submarine canyons}

Large Plio-Quaternary erosive structures are observed on the modern outer shelf, in the vicinity of the modern and paleo-shelf breaks. They consist of major (6 km wide, $1 \mathrm{~km}$ deep) or smaller (600 $\mathrm{m}$ wide, $60 \mathrm{~m}$ deep) incisions. Their internal structures are characterized by continuous divergent reflectors, with localized chaotic facies suggesting slides or slumps.

Several major phases of canyon incision are observed on most of the seismic profiles (Fig. 9).

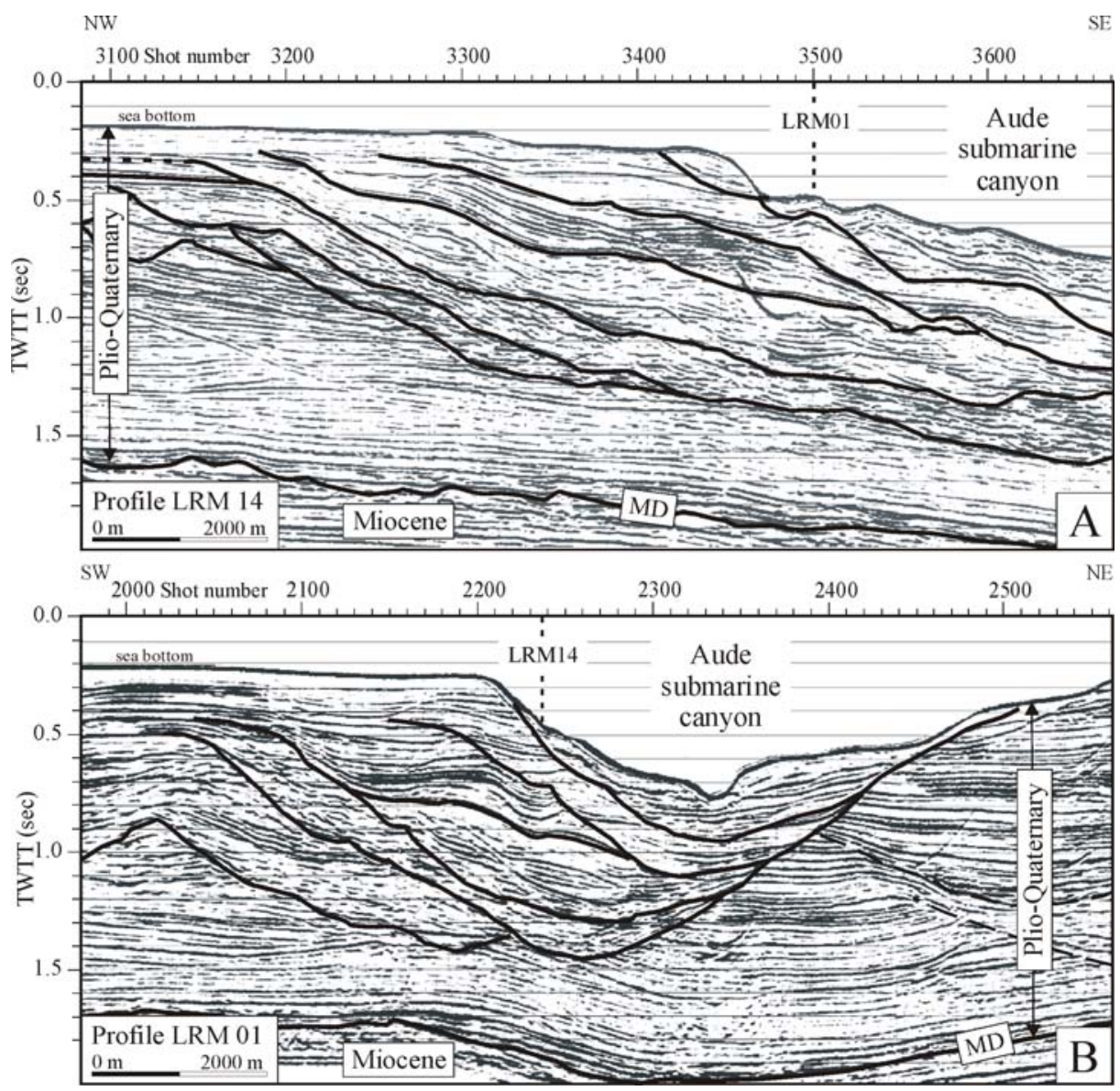

Figure 9. (A) Section of the LRM14 dip seismic line showing the seaward progradation of the Aude submarine canyon beneath the outer shelf. (B) Section of the LRM01 strike seismic line illustrating its westward migration. MD: Messinian Discordance. See figure 1 for profile location. 
The mapping of the paleo-canyons indicates that large seaward shifts (18 km on line LRM18, Fig. 3-B) in the position of the canyons and the shelf break took place during the Plio-Quaternary. Strike lines illustrate the along-slope migration of the canyon heads (Fig. 9B and Fig. 8-C), whereas dip lines show their seaward progradation (Fig. 9-A and Fig. 3). Chronostratigraphic correlations with the boreholes permit us to propose a time frame for the beginning of canyon incision development. The oldest buried canyon observed within the study area (top of U2 (Fig. 8-B)) is middle to late Pliocene in age (between 3.8 and $1.8 \mathrm{Ma}$ ). Large-scale canyons, similar in size to modern canyons, really developed during the deposition of U3 (Fig. 8-C). Their maximum wall height is $0.75 \mathrm{sec}$ TWTT in the study area (Fig. 9-B), roughly similar to that of the modern Lacaze-Duthiers canyon (Fig. 1). No paleocanyons cut the inner-to-middle modern shelf but a few paleo-erosional structures are observed on the present middle shelf and are interpreted as fluvial features (Fig. 4-A).

\subsection{Clinoform progradation}

Dip seismic lines provide evidence for an overall seaward progradation of the margin exceeding 60 to $100 \mathrm{~km}$ during the Plio-Quaternary. This interval consists of thick prograding clinoform wedges, with changes in their characteristics through time and space. During deposition of unit U1, the shelf prograded rapidly over the MES, the shelf break position advancing by at least $35 \mathrm{~km}$ during this $1.5 \mathrm{Ma}$ long period. Conversely, without considering sedimentary compaction, clinoform height (measured between the offlap break and the bottomset) varies from 300 to 600 m (Fig. 10-A). As seen in Figure 11, U1-a(s) and U1-b(s) (=U1(s)) exhibit concave seaward clinoform fronts in plan view. 

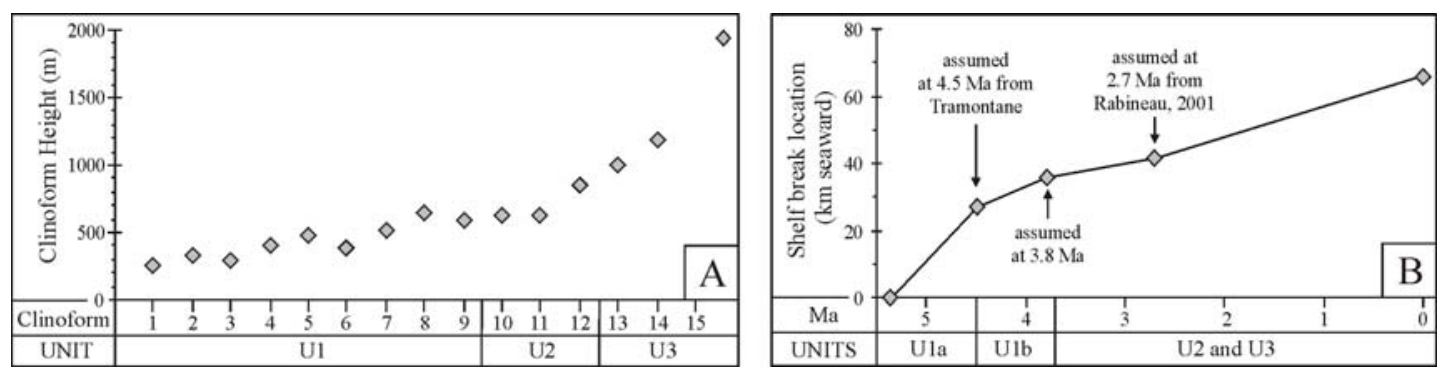

Figure 10. (A) Dip evolution of clinoform height (measured between the offlap break and the bottomset) on line LRM10. (B): Evolution of the progradation of the margin since the infilling of the Pliocene rias, assuming U1(s) formed around 3.8 Ma.
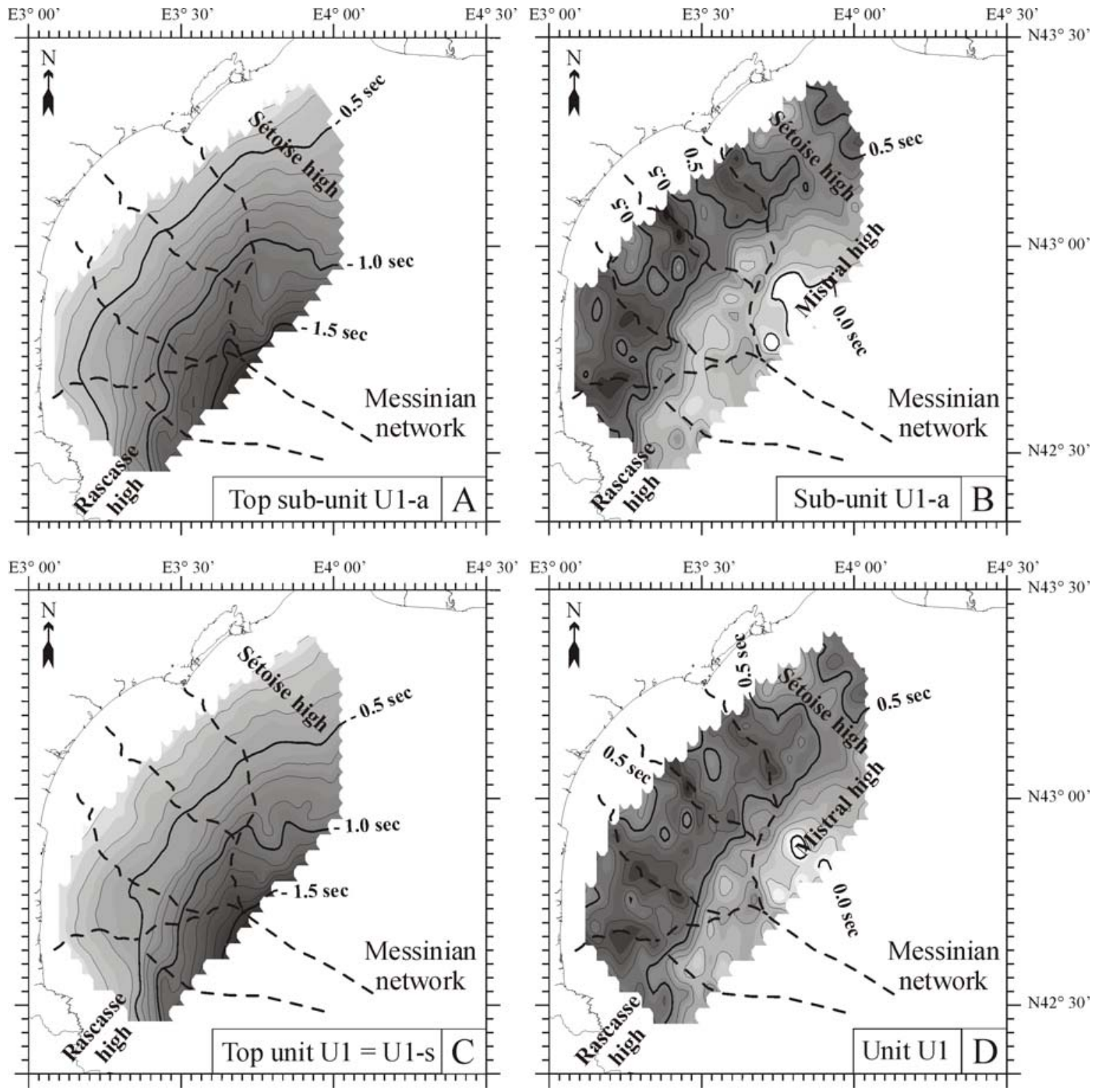

Figure 11. Isochron maps of (A) the top of sub-unit U1-a and (B) its thickness; (C) the top of unit U1 and (D) its thickness. Note the concave shape of the clinoform front (A) and the thickening of deposits in the Messinian valleys lows (B, D). 
Following the major seaward shift associated with U1, the margin continued to prograde over the Messinian shelf but the rate of progradation decreased (Fig. 10-B). The shelf break position advanced by $26 \mathrm{~km}$ during $\mathrm{U} 2$ and $\mathrm{U} 3$, that is in about 3.8 Ma, assuming that U1(s) was generated during the global sea-level fall at the end of the Lower Pliocene. During the deposition of units U2 and U3, clinoform height increased considerably, from 600 m to $2000 \mathrm{~m}$. A change in the curve trend is clearly indicated within U3 (Fig. 10-A). During the same period, submarine canyon incisions appeared and increased in size as the shape of the clinoform front transforming progressively to a more linear shape.

\section{Discussion}

Our data document the reconstruction of the western Gulf of Lion margin, from an eroded margin generated during the salinity crisis, to the present day continental platform with a well-defined shelf break at about 120-150 m water depth (Fig. 12). It is worth noting that it took about 5.3 Ma to rebuild the margin, the present shelf-break, about $60 \mathrm{~km}$ from the shoreline, is located approximately at the same position as the pre-Messinian shelf-break (Gorini, 1993).

Three stages of development are proposed from the interpreted seismic data and correlation with boreholes:

- Stage 1 includes unit U1 and is interpreted to correspond to the Lower Pliocene.

- Stage 2 includes unit U2 and starts around the beginning of the Middle Pliocene. We estimate that the end of this stage occurred between Mid to Late Pliocene.

- Stage 3 includes unit U3. It began between the Mid to Late Pliocene and continued throughout the entire Quaternary.

The sedimentary history during these stages is discussed below. 


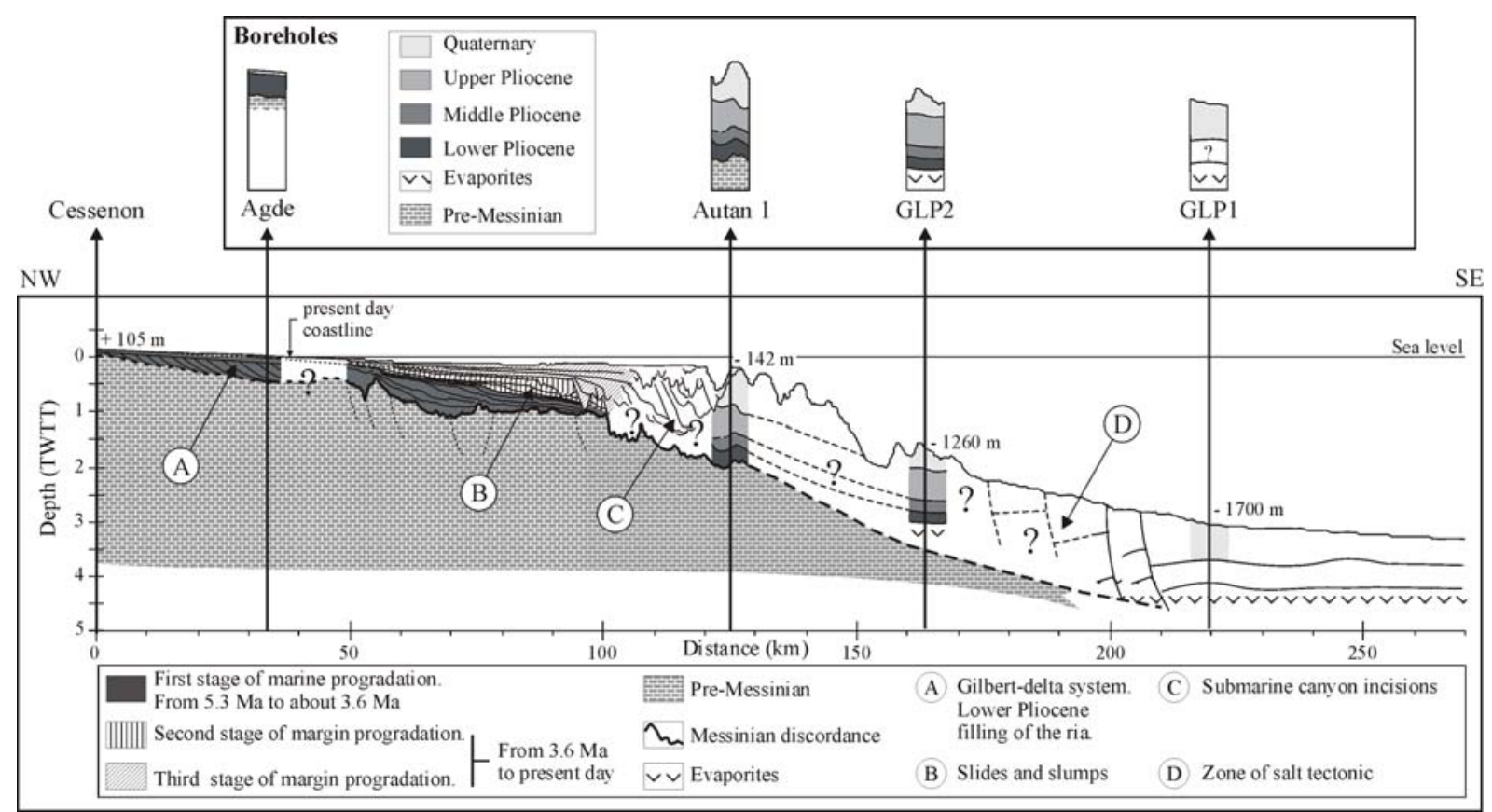

Figure 12. Onshore-offshore composite profile from the Orb-Hérault Pliocene ria down to the abyssal plain. See figure 1 for location.

\subsection{A rapid Post-Messinian sea-level rise}

With the re-filling of the Mediterranean Basin by Atlantic water, a global rise in sea level succeeded the desiccation of the basin and marked, at 5.3 Ma, the end of the Messinian Salinity Crisis. Scant information exists about how rapid this rise was and actually time scale ranges between 1000 and 170,000 years depending of the authors (Clauzon et al., 1996; Krijgsman et al., 1999).

Analysis of material taken from the Tramontane borehole shows the presence of $G$. Margaritae just above MES, which suggests middle-to-outer shelf depositional environments. This supports the idea of rapid marine Zanclean (Early Pliocene) transgression. However, the Tramontane borehole was drilled on a Messinian topographic high (Fig. 6-A) and transgressive sediments may have been deposited in the Messinian lows (thalwegs). The major argument in favor of a rapid transgression, at least over the modern inner-to-middle 
shelf, is the absence on the seismic resolution scale of any transgressive systems tracts above the MES. Beneath the modern inner shelf, the Pliocene clinoforms of sub-unit U1-a directly downlap on the MES discordance, showing that the new margin prograded directly over the eroded Miocene surface. If a transgressive systems tract exists, it must be thinner than the resolution of our seismic profiles (less than 30-50 m). However, the interval M1 in the Mistral borehole indicates that it can be considered like a transgressive interval deposited at the end of the salinity crisis, but we have no evidence of the age of this interval. In any case, if there was a transgressive interval, it was small at the scale of the platform.

\subsection{Stage 1}

As a consequence of the Miocene margin erosion during the salinity crisis and of the subsequent rapid rise in sea level, the Pliocene sedimentation starts in a particular morphosedimentary context on the Gulf of Lion shelf. The initiation of a new continental shelf on top of the older shelf occurred as follows:

- First, following the Zanclean transgression, depocenters rapidly shifted landward and filled flooded Messinian canyon heads with Gilbert deltas (Gilbert, 1885), along the Early Pliocene coastline (Clauzon et al., 1987).

- Then shelf reconstruction proceeded over the eroded Miocene inner shelf by deposition of unit U1. The transitional zone located between the Gilbert deltas observed on land and the oldest Pliocene clinoform observed on the seismic data is badly documented because of the difficulties in acquiring seismic data in very shallow water.

During this first stage of reconstruction, Early Pliocene clinoforms of unit U1 prograded across the present day inner-shelf, filling the available accommodation space created during the salinity crisis. Messinian valley lows constitute local depocenters trapping progradational deltaic lobe sediments. The isopach map of units U1-a and U1 shows the infilling of the major depressions by the Early Pliocene sediments (Fig 10-B and -D). Because of sliding structures, 
the sedimentary architecture can be locally complex, as is demonstrated by the presence of the hummocky seismic facies that is restricted to the topographic lows (Fig. 5). As it is shown in Figure 11, the concave shapes of the clinoform fronts are probably related to the pre-existing Miocene shelf morphology as progradation on the topographic highs (Sétoise high and Rascasse high) is more rapid than in the Messinian lows where accommodation is higher.

This first period of shelf progradation roughly corresponds to the global high stand of the Lower Pliocene with a marked sea-level fall that probably corresponds to surface U1(s). During the same period, sediments coming from the Languedoc-Roussillon rivers are trapped on the inner-to-middle shelf (Fig. 12), as attested by the thick section of Lower Pliocene sediments recovered in the Messinian lows (800 m on line LRM13, Fig. 8-A). The deep basin is poorly fed with sediments from the Gulf of Lion, as attested by the thin section (385 m) of Lower Pliocene sediments recovered on the rise, in GLP2 borehole (Dos Reis, 2001, see also borehole position in figure 1).

\subsection{Stage 2}

The second step in margin reconstruction began around 3.8 Ma. During that period, the shelf reconstruction proceeded over the eroded Miocene inner shelf by deposition of unit $\mathrm{U} 2$.

During deposition of U2, the shelf break position shifted seaward by $10 \mathrm{~km}$. As previously described, clinoform progradation across the Messinian seaward dipping surface resulted in an increase in clinoform height from 650 to $850 \mathrm{~m}$ (Fig. 10-A). By the end of U2, Lower and Middle Pliocene sediments have filled in the Messinian lows and the shelf-break front displays a linear shape.

The upper limit of U2 cannot be dated precisely from borehole data. It correlates with the beginning of the submarine canyons incisions perhaps as a result of sea level changes. Interpretation of very high-resolution seismic data coupled with stratigraphic modelling 
allowed Rabineau (2001) to propose an age to Late Quaternary sedimentary sequences and erosional surfaces. This result was extrapolated by this author on ELF seismic data on the platform and allowed to propose an age of 2.7 Ma for top of U2. Compared to the amount of sediment deposited on the shelf during the Lower Pliocene (in green color in figures 3 and 8), this extrapolation implies that only a small amount of Middle Pliocene sediments deposited over the shelf, between 3.8 and 2.7 Ma (see yellow color in figures 3 and 8). This observation is in contradiction with the thickness $(700 \mathrm{~m}$ ) of Middle Pliocene sediments preserved at the Autan borehole (Fig. 3-A and Fig. 7). In addition, seismic line LRM28 (Fig. 3-A) illustrates the geometrical complexity in correlating the top of unit U2 (in yellow) and the top of the Middle Pliocene sequence identified at the Autan borehole. However, we also have to take into account the fact that Autan borehole is located in the middle of the Gulf of Lion and therefore might also receive sediments directly from the North (the Rhone system) and not only from pyreneo-languedocian rivers). A fuller understanding of this interval would require additional seismic data in the Rhone Autan area and full-recovery borehole on the shelf.

Stage 2 constitutes a transitional stage from stage 1 (progradation) and stage 3 (aggradation and numerous canyon incisions). U2 was disturbed by instabilities (Fig. 3, B, shot points 2300 to 2700$)$.

\subsection{Stage 3}

The third step in margin reconstruction corresponds to U3. During this period, Messinian valleys no longer constituted local depocenters for sedimentation as they had been filled in by sediment during the previous stages. The shape and size of the prograding clinoforms changed and slope sedimentation was modified as submarine canyon incisions developed.

Late ? Pliocene to Quaternary clinoforms of unit U3 that developed across what is now the middle to outer shelf are higher and steeper than their predecessors (Fig. 10-A). While the 
oldest clinoforms were only about $300 \mathrm{~m}$ high, younger clinoform heights range from $800 \mathrm{~m}$ to $2000 \mathrm{~m}$, the foresets becoming steeper with time from 5 to $8^{\circ}$ (excepted present day slope which is about $2^{\circ}$ ). Numerical simulations of clinoform progradation predict that the dip angle should increase with clinoform height (Pirmez et al., 1998), because a steeper angle is required to transport the greater amount of sediment required to prograde a higher clinoform. If the change in clinoform height and slope during both stage 1 and 2 is a natural result of their progradation over the initial Messinian seaward-dipping surface, then the abrupt increase in clinoform height during deposition of U2 could have resulted from an increase in the gradient of the underlying Messinian surface. The present day longitudinal gradient of the Messinian valleys displays a marked change around the outer shelf (Lofi, 2002). In this area, the Messinian slope increases from about $0.5-1 \%$ to $3.2 \%$. This change is clearly observed around shot point 2850 on line LRM10 (Fig. 3-C) and around shot point 1800 on line LRM04 (Fig. 3-D).

During phases 2 and 3, on seismic lines LRM10 and LRM18, the rate of progradation slowed down, from more than 20km/Ma during Lower Pliocene (stage 1) to less than $10 \mathrm{~km} / \mathrm{Ma}$ since U1(s) (Fig. 10-B). However, this observation doesn't mean that the sediment fluxes decreased during the same period. Like wise, this is not in contradiction with an increase in sediment supply since about 3 Ma due to increased sediment fluxes in relation with the growth of glaciers in the Alps and the Pyreneans. As the clinoform height increases, a larger amount of sediment is needed for the depositional shelf-break to prograde over the same distance.

As there is an overall trend for sea level fall since about $3.8 \mathrm{Ma}$ (Haq et al., 1987, Shackleton et al., 1995), a high total subsidence rate (including sediment loading) caused the creation of accommodation space. In addition, the development of submarine canyons may have played an important role in reducing shelf progradation by increasing slope erosion and more importantly by favoring direct transfer of sediments from estuaries to the deep sea during low stands of sea level. The appearance and development of submarine canyons incising the 
successive shelf breaks is probably related to several interconnected factors: (a) the increase in slope gradient and clinoform height with a critical gradient value for slope stability; (b) the increase in sediment supply and (c) the occurrence of higher frequency fluctuations in sea level, particularly since about 3 Ma. All these factors contribute to increased slope instabilities and triggered submarine canyon creation.

During the third stage of shelf reconstruction, a great deal of evidence demonstrates that a large amount of sediment was transferred towards the slope and the deep basin through newly created submarine canyons: the rather limited amount of the Quaternary deposits on the present day inner and outer shelf (less than 300 meters at the Mistral borehole, Fig. 6-B)); the filling of canyon heads (up to $1 \mathrm{~km}$, Fig. 8-C) and the development of large Upper Pliocene to Quaternary sedimentary bodies in the basin (900 m of Quaternary at the GLP1 borehole, Dos Reis, 2001).

During deposition of U3, the depocenter is located on the outer shelf, slope and basin. As the subsidence of the margin took the form of a seaward tilt estimated to reach $250 \mathrm{~m} / \mathrm{Ma}$ at 70 $\mathrm{km}$ from the coast (around the Aude-Herault canyon, Rabineau, 2001), the subsidence rate is higher on the outer shelf. Bessis and Burrus (1986) calculated that the loading effect of sediments contributed by 40 to $50 \%$ to the total post-rift subsidence of the Gulf of Lion margin. Consequently, we believe that a part of the high rate of accommodation creation is due to the loading effect of sediments:

\section{Conclusions}

A new data set of higher-resolution multi-channel seismic profiles reveals the major phases of margin reconstruction following the Messinian Salinity Crisis in the Western Gulf of Lion. Following a rapid Zanclean marine transgression, attested by the extremely limited transgressive systems tract above the Messinian erosion surface, Pliocene and Quaternary sediments prograded over the margin, building a new continental shelf and clinoforms over 
the eroded Miocene shelf. Seismic interpretation allows us to identify three distinct seismic units, partly tied to boreholes, and to propose a scenario for the evolution of the margin since the end of the Messinian Salinity Crisis.

- During a first stage, running from 5.3 to about 3.8 Ma, the margin prograded rapidly in a context of high sea level and reestablished a shelf-slope morphology (unit U1). The position of depocenter was controlled by the pre-existing topography of the Miocene shelf inherited from the Messinian crisis. Sediments supplied by streams were trapped on the present day shelf. In the absence of any submarine canyon, the deep basin was poorly fed with Lower Pliocene material.

- During a second stage, beginning around 3.8 Ma, shelf reconstruction continued (unit U2). This period constitutes a transitional stage from the relative still-stand of sea level characterizing the Lower Pliocene, in which there are no submarine canyons, to an ensuing period of in which large and numerous submarine canyons develop.

- During a third stage, lasting to the present day, high-latitude glaciations and increased sealevel fluctuations, together with increased sediment supply from the Alps and the Pyrenees, increased delivery of sediment to the slope and the deep basin. The rate of margin progradation decreased and is attributed to the increase in clinoform height, the appearance and development of large submarine canyons and the higher subsidence rate on the outer shelf.

This study has shown that the Gulf of Lion is an ideal study area for the understanding of passive continental margin growth. First of all, the Messinian event exposed the margin to deep subaerial erosion creating huge accommodation space for subsequent sedimentation. Secondly, the large sediment supply during the Pliocene-Quaternary caused the progradation of well-developed clinoforms, and, finally, continuous rapid subsidence enabled excellent preservation of the deposits on the margin. 


\section{Acknowledgements}

We thank Francisco Sierro for his invaluable assistance in reinterpreting the paleontological data. We especially acknowledge journal reviewers, J.C. Faugères and M. Tesson, who improved the manuscript through very constructive comments. We also wish to thank TOTAL-FINA-ELF EP for giving us access to the seismic data used in this study and allowing us to publish some of the LRM96 profiles. Support for this project has come from “URM17”, “GDR Marge” and "ECLIPSE” programs. Support for the US participants was provided by NSF grant OCE 99-11866. 


\section{References}

Aloïsi, J.-C., 1986. Sur un modèle de sédimentation deltaïque : contribution à la connaissance des marges passives. Thèse de 3ème cycle, Université de Perpignan, 162 pp.

Alvarez, W., 1972. Rotation of the Corsica-Sardinia microplate. Nature, Physical Science, 235(58): 103-105.

Auzende, J.-M., Bonnin, J., Olivet, J.-L., Pautot, G. and Mauffret, A., 1971. Upper Miocene salt layer in the western Mediterranean basin. Nature, Physical Science, 230(12): 82-84.

Backman, J., 1979. Pliocene biostratigraphy of DSDP sites 111 and 116 from the North Atlantic Ocean and the age of Northern Hemisphere glaciation. Stockholm, Contributions in Geology, 32: 115-137.

Barber, P.M., 1981. Messinian subaerial erosion of the Proto-Nile delta. Marine Geology, 44(3-4): 253-272.

Berggren, W.A., Hilgen, F.J., Langereis, C.G.; Kent, D.V., Obradovich, J.D., Raffi, I., Raymo M.E. and Shackleton, N.J., 1995. Late Neogene chronology; new perspectives in highresolution stratigraphy. Geological Society of America Bulletin. 107(11): 1272-1287.

Berné, S., Lericolais, G., Marsset, T., Bourillet, J.-F. and De Batist, M., 1998. Erosional offshore sand ridges and lowstand shorefaces: examples from tide- and wave-dominated environments of France. Journal of Sedimentary Research, 68(4): 540-555.

Berné, S., Loubrieu, B., and the CALMAR shipboard party, 1999. Canyons et processus sédimentaires récents sur la marge occidentale du Golfe du Lion. Premiers résultats de la campagne Calmar. Comptes Rendus de l'Académie de Sciences, Paris, 328: 471-477.

Bessis, F. and Burrus, J., 1986. Etude de la subsidence de la marge du Golfe du Lion (Méditerranée occidentale). Bulletin des Centres de Recherche, Exploration et Production de Elf Aquitaine, 10(1): 123-141.

Biju-Duval, B., Letouzey, J., Montadert, L., Courrier, P., Mugniot, J.F. and Sancho, J., 1974. Geology of the Mediterranean Sea basins. In: Burk, C.A. and Drake, C.L. (Eds.), The Geology of Continental Margins. Springer-Verlag, New York, pp.695-721.

Burrus, J. and Audebert, F., 1990. Thermal and compaction processes in a young rifted basin containing evaporates: Gulf of Lion, France. American association of pertroleum geologists, 74(9):1420-1440.

Calvet, M., 1986. Néotectonique et mise en place des reliefs dans l'est des Pyrénées; l'exemple du horst des Albères. Revue de Géologie Dynamique et de Géographie Physique, 26: $119-130$. 
Cita, M.B., 1975a. Studi sul Pliocene e gli strati di passagio dal Miocene al Pliocene. VII. Planktonic foraminiferal biozonation of the Mediterranean Pliocene deep sea record. A revision. Rivisita Italiana di Paleontologia, Milano, 81(4): 527-544.

Cita, M.B. and Ryan, W.B.F. (Eds.), 1978. Messinian erosional surfaces in the Mediterranean. Marine Geology, 27(3/4): 193-365.

Cita, M.B., Rio, D. and Sprovieri, R., 1999. The Pliocene series: chronology of the type Mediterranean record and standard chronostratigraphy. American Association of Stratigraphic Palynologists Foundation: 49-63.

Clauzon, G., 1982. Le canyon messinien du Rhône : une preuve décisive du "desiccated deepbasin model" (Hsü, Cita et Ryan, 1973). Bulletin de la Société Géologique de France, (7), 24(3): 231-246.

Clauzon, G., Aguilar, J.P. and Michaux, J., 1987. Le bassin pliocène du Roussillon (PyrénéesOrientales, France) : exemple d'évolution géodynamique d'une ria méditerranéenne consécutive à la crise de salinité messinienne. Comptes Rendus de l'Académie de Sciences, Paris, 304(11): 585-590.

Clauzon, G., Suc, J.-P., Gautier, F., Berger, A. and Loutre, M.-F., 1996. Alternate interpretation of the Messinian salinity crisis: controversy resolved? Geology, 24(4): 363-366. Comas, M.C., Zahn, R., Klauss, A. et al. (eds), Proceedings of the Ocean Drilling Program, Part A: Initial Reports. U.S. College Station, TX, 161: 1023pp.

Cravatte, J., Dufaure, P., Prim, M. and Rouaix, S., 1974. Les sondages du Golfe du Lion, stratigraphie, sédimentologie. Notes \& Mémoires. Compagnie Française des Pétroles, 11: 209-274.

Dos Reis, T., 2001. La Tectonique salifère et son influence sur l'architecture sédimentaire quaternaire de la marge du Golfe du Lion - Méditerranée Occidentale. Thèse 3ème cycle, Université Pierre et Marie Curie de Paris VI. 373pp.

Droz, L., 1991. Morphologie, structure et comparaison des deep-sea fans du Rhône, de l'Indus et du Var. Mémoire d'habilitation à diriger des recherches, Université de Paris VI, 254 pp.

Gautier, F., Clauzon, G., Suc, J.-P., Cravatte, J. and Violenti, D., 1994. Age et durée de la crise de salinité messinienne. Comptes Rendus de l'Académie des Sciences, Paris, 318(2): 1103-1109.

Gilbert, G.K. 1885. The topographic features of the shorelines, U.S. Geol. Surv. Rep., Washington, DC 5, 75-123. 
Gorini, C., 1993. Géodynamique d'une marge passive : le Golfe du Lion (Méditerranée occicentale). Thèse 3ème cycle, Université Paul Sabatier de Toulouse III. 264pp.

Guennoc, P., Gorini, C. and Mauffret, A., 2000. Histoire géologique du golfe du Lion et cartographie du rift oligo-aquitanien et de la surface messinienne. Géologie de la France, 3: 67-97.

Haq, B.U., Hardenbol, J. and Vail, P., 1987. Chronology of fluctuating sea levels since Triassic (250 million years ago to present). Science, 235(4793): 1156-1167.

Hilgen, F.J., 1991. Extension of the astronomically calibrated (polarity) time scale to the Miocene/ Pliocene boundary. Earth and Planetary Science Letters, 107(2):349-368.

Hsü, K.J., Cita, M.B. and Ryan, W.B.F., 1973. Origin of the Mediterranean evaporites. In : Ryan, W.B.F, Hsü, K.J. et al. (Eds), Initial Reports of the Deep-Sea Drilling Project. U.S. Government Printing Office, Washington, D.C., 13: 1203-1231.

Keigwin, L.D. and Thunnel, R.C., 1979. Middle Pliocene climatic change in the western Mediterranean from faunal and oxygen isotopic trends. Nature, 282: 294-296.

Krijgsman, W., Hilgen, F. J., Raffi, I., Sierro, F. J. and Wilson, D. S., 1999. Chronology, causes and progression of the Messinian salinity crisis. Nature, 400(6745): 652-655.

Lofi, J., 2002. La Crise de Salinité Messinienne : conséquences immédiates et différées sur l'évolution sédimentaire de la marge du Golfe du Lion. Thèse 3ème cycle, Université Lille I. 277pp.

Lourens, L.J., Antonarakou, A., Hilgen, F.J., Van Hoof, A.A.M., Vergnaud-Grazzini, C. and Zachariasse, W.J., 1996. Evaluation of the Plio-Pleistocene astronomical timescale. Paleoceanography, 11(4): 391-413.

Mauffret, A. and Gorini, C., 1996. Structural style of the Camargue area and western Provençal basin (Southern France), geodynamic consequences. Tectonics, 15: 356-375.

Menard, H.W., Smith, S.M. and Pratt, R.M., 1965. The Rhone deep-sea Fan. In: Whittard, W.F. and Bradshaw, R. (Eds.), Submarine Geology and Geophysics (Proceedings of the 17th Symposium of the Colstan Research Society). Buttersworht, London, 271-285.

Mitchum, R.M. Jr. and Vail, P.R., 1977. Seismic stratigraphy and global changes of sea-level, part 7: stratigraphic interpretation of seismic reflection patterns in depositional sequences. In: Payton, C.E. (Ed.), Seismic stratigraphy - Applications to Hydrocarbon Exploration. Memoir of the American Association of Petroleum Geologists, Tulsa, 26: 135-144. 
Nesteroff, W.D., 1973. Mineralogy, petrography, distribution, and origin of the Messinian Mediteranean evaporites. In: Ryan, W.B.F, Hsü, K.J. et al. (Eds), Initial Reports of the DeepSea Drilling Project. U.S. Government Printing Office, Washington, D.C., 13: 673-694.

Pirmez, C., Pratson, L.F. and Steckler, M.S., 1998. Clinoform development by advectiondiffusion of suspended sediment: Modeling and comparison to natural systems. Journal of Geophysical Research, 103, B10: 24,141-24,157.

Rabineau, M., 2001. Un modèle géométrique et stratigraphique des séquences de dépôt quaternaires sur la marge du Golfe du Lion : enregistrement des cycles climatiques de 100 000 ans. Thèse 3ème cycle, Université de Rennes I. 455pp et Annexe.

Ryan, W.B.F., 1973. Geodynamic implication of the Messinian crisis of salinity. In: Drooger, C. W., et al. (eds.), Messinian events: Amsterdam, Elsevier: 26-38.

Ryan, W.B.F., 1976. Quantitative evaluation of the depth of the Western Mediterranean before, during, and after the Late Miocene salinity crisis. Sedimentology, 23: 791-813.

Shackleton, N.J., Hall, M.A. and Pate, D., 1995. Pliocene stable isotope stratigraphy of site 846. Proceeding of the Drilling Program, Scientific Results, 138:337-355.

Sprovieri, R., 1993. Pliocene-Early Pleistocene astronomically forced planktonic foraminifera abundance fluctuations and chronology of Mediterranean calcareous plankton bio-events. Rivisita Italiana de Paleontologia e Stratigrafia, Milano, 99(3): 371-414.

Steckler, M.S. and Watts, A.B., 1980. The Gulf of Lion: subsidence of a young continental margin. Nature, 287: 425-429.

Steckler, M.S., Mountain, G.S., Miller, K.G. and Christie-Blick, N., 1999. Reconstruction of Tertiary progradation and clinoform development on the New Jersey passive margin by 2-D backstripping.

Suc, J.-P. and Bessais, E., 1990. Pérennité d'un climat thermo-xérique en Sicile avant, pendant, après la crise de salinité messinienne. Comptes Rendus de l'Académie de Sciences, 310(2): 1701-1707.

Suc, J.-P., Bertini, A., Combourieu-Nebout, N., Diniz, F., Leroy, S., Russo-Ermolli, E., Zheng, Z., Bessais, E. and Ferrier, J., 1995. Structure of West Mediterranean vegetation and climate since 5.3 ma. Acta Zoologica Cracoviensia, 38(1): 3-16.

Torres, J., 1995. Analyse détaillée du transfert de sédiments du continent vers le bassin : le Quaternaire terminal au large du delta du Rhône (Méditerranée nord-occidentale), Thèse 3ème cycle, Université de Bretagne occidentale, Brest, 353 pp. 
Tesson, M., Gensous, B., Allen, G.P. and Ravenne, C., 1990. Late Quaternary lowstand wedges on the Rhône Continental Shelf, France. Marine Geology, 91: 325-332.

Zachos, J. Pagani, M., Sloan, L., Thomas, E., Billups, K., 2001. Trends, Rhythms, and Aberrations in Global Climate 65 Ma to Present. Sciences, 292:686-693. 